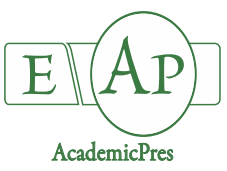

Masocha BL et al. (2021)

Notulae Botanicae Horti Agrobotanici Cluj-Napoca

Volume 49, Issue 2, Article number 12344

DOI: $10.15835 /$ nbha49312344

Research Article

\title{
Improving Jatropha curcas L. photosynthesis-related parameters using poultry litter and its biochar
}

\section{Boitshwarelo L. MASOCHA ${ }^{1 *}$, Oagile DIKINYA ${ }^{1}$, Baleseng MOSEKI ${ }^{2}$}

\author{
${ }^{1}$ University of Botswana, Department of Environmental Science, Private Bag 0022, Gaborone, \\ Botswana;blmasocha@gmail.com (*correspondingauthor);dikinyao@ub.ac.bw \\ ${ }^{2}$ University of Botswana, Department of Biological Sciences, Private Bag0022, Gaborone, Botswana; mosekib@ub.ac.bw
}

\begin{abstract}
Poultry litter and biochar contribute to improved plant growth due to their high nutrient content. However, to the best of our knowledge, how incorporating poultry litter and its biochar in soil affects photosynthesis-related parameters of Jatropha curcas L. has not been reported. Therefore, a greenhouse pot experiment was conducted using a complete randomised design with three replicates per treatment to determine the effects of poultry litter, biochar pyrolysed at $350^{\circ} \mathrm{C}$ and $750^{\circ} \mathrm{C}$ at different application rates $(0$, $0.5,1,2,3 \mathrm{gkg}^{-1}$ ) on Jatropha curcas L. photosynthesis parameters. The control plants recorded the lowest values of photosynthesis-related parameters compared to the treated plants except for water use efficiency. The study observed a significant $(\mathrm{P}<0.05)$ increase in leaf surface area $\left(1807 \mathrm{~m}^{2}, \mathrm{PL}\right)$, dark-adapted $\mathrm{F}_{\mathrm{v}} / \mathrm{F}_{\mathrm{m}}$ ratio, carbon dioxide uptake, and transpiration rate for $\mathrm{PL}$ and $\mathrm{BC} 350$ with increased application rates, compared to BC750 treatments. BC350 treated plants exhibited higher values (0.79) of Light-adapted Fv'/Fm'. The quantum yield of PSII electron transport displayed an increase with an application rate of $3 \mathrm{gkg}^{-1}$ in PL (0.75) treated soils. Comparing organic amendments used, BC350 exhibited a significantly higher value of carbon dioxide uptake rate $\left(2.67 \mu \mathrm{mol} \mathrm{m}^{-2} \mathrm{~s}^{-1}\right)$ and transpiration rate $\left(2.20 \mathrm{mmol} \mathrm{m}^{-2} \mathrm{~s}^{-1}\right)$; however, WUE increased at an application rate of $3 \mathrm{gkg}^{-1}$ in $\mathrm{BC} 750\left(3.8 \mu \mathrm{mol}\left(\mathrm{CO}_{2}\right) \mathrm{mol}^{-1}\left(\mathrm{H}_{2} \mathrm{O}\right)\right)$ treated plants. The study results indicate that poultry litter and biochar produced at a lower temperature significantly improved photosynthesis parameters than biochar produced at a higher temperature.
\end{abstract}

Keywords: biochar; chlorophyll fluorescence; Jatropha curcas L.; photosynthesis parameters; poultry litter

\section{Introduction}

Poultry litter is one among the organic fertilisers used as an alternate source of plant nutrients and it has been deliberated for the past years to improve soil properties and enhancing crop quality and yields (Khan et al., 2007; Bolan et al., 2010; Revell et al., 2012; Li et al., 2018; van Zwieten, 2018; Bohara et al., 2019). Moreover, organic fertilizers are an essential contribution of organic matter that improves soil's physical and chemical characteristics (Onwu et al., 2018) and has a beneficial effect on increasing the soil's organic matter content (Scotti et al., 2015). Furthermore, poultry litter has high NPK and microelements (Steiner et al., 2010) essential for plant growth. Nonetheless, the study on the photosynthesis-related parameters concerning soil

Received: 14 Apr 2021. Received in revised form: 18 May 2021. Accepted: 28 May 2021. Published online: 28 Sep 2021.

From Volume 49, Issue 1, 2021, Notulae Botanicae Horti Agrobotanici Cluj-Napoca journal uses article numbers in place of the traditional method of continuous pagination through the volume. The journal will continue to appear quarterly, as before, with four annual numbers. 
nutrient provision by poultry litter and its biochar has received less attention even though photosynthesis parameters are among the key factors contributing to plant growth and determining crop health. Additionally, the photosynthesis rate is a critical trait for assessing plant fitness and its general performance (Xu et al., 2015).

Although poultry litter has been useful as a soil amendment, some studies (Chan et al., 2008; Laghari et al., 2016; Bohara et al., 2019) have shown that organic waste conversion into biochar makes them even more effective than the feedstock. Biochar refers to the carbon-rich material produced from the slow pyrolysis (heating in the absence of oxygen) of biomass (Chan et al., 2008). Biochar production provides a beneficial alternative method of improving poultry litter quality, ultimately improving plant growth (Xu et al., 2015) and soil fertility (Roberts et al., 2009). Comparative to feedstock, biochar resists decomposition, effectively sequestering carbon (Biederman and Harpole, 2013). It also acts as an absorber of ammonia $\left(\mathrm{NH}_{3}\right)$ and watersoluble ammonium $\left(\mathrm{NH}_{4}^{+}\right)$and might reduce nitrogen losses through $\mathrm{NH}_{3}$ volatilization (Steiner et al., 2010). Additionally, it can also stimulate mineralization, supply Nitrogen $(\mathrm{N})$ embodied in the biochar to biomass, reduce nitrous oxide $\left(\mathrm{N}_{2} \mathrm{O}\right)$ emissions (Clough et al., 2013) and modify soil $\mathrm{N}$ dynamics (Clough and Condron, 2010; Clough et al., 2013). Though nutrients supply from either raw feedstock or biochar may determine crop quality and yields, a physiological process like photosynthesis contributes to plant health but relies on plant nutrients.

Plant nutrients supply maintains the synthesis of critical photosynthetic components (Kalaji et al., 2018) that avoids photosynthetic apparatus disruption. Hence, it is mandatory to retain the required optimum soil nutrient content level to improve photosynthetic efficiency, including apparatus structure and functions and PSII photochemistry (Kalaji et al., 2014). Besides, nutrient availability directly contributes to protein and chlorophyll synthesis (Chapin III, 1980), and the lower the nutrient supply, the lower the protein and chlorophyll synthesis rate, and the decline of light-saturated photosynthesis rates (Chapin III, 1980). For instance, leaf nitrogen concentration needs to be optimal as it is a component of photosynthetic enzymes and chlorophyll (Jongschaap et al., 2007a). Nitrogen is one of the most biologically essential elements. It can regulate leaf steady-state photosynthesis through several strategies, such as a considerable investment of leaf $\mathrm{N}$ to Rubisco and its involvement in the stomatal opening (Xu et al., 2015; Sun et al., 2016). As a result, organic amendments are an alternate option to maintain plant nutrients where they are limited and improve photosynthesis-related parameters.

Jatropha curcas L. commonly called Jatropha (Leela et al., 2011) or physic nut (Tatikonda et al., 2009) is a multipurpose, low nutrient requiring perennial shrub that can survive in marginal areas (Laird, 2008; Blesgraaf, 2009; Agbogidi et al., 2013) and semi-arid condition (Kumar and Sharma, 2008; Jongh and van der Putten, 2010; Geply et al., 2011; Rajaona et al., 2012). Hence, it is considered as a low nutrient requiring plant (Blesgraaf, 2009; Agbogidi et al., 2013). Moreover, Jatropha has been documented as one of the emerging and potential renewable biofuel plant (Mahajan et al., 2009; Dias et al., 2012) with high potential for socioeconomic development (Matsumoto et al., 2014) where there is high price of inputs. Jatropha provides a viable alternative in semi-arid areas, contributing to increased resource use efficiency, erosion control (Dias et al., 2012), local energy supply and rural development (Jongschaap et al., 2007b). Furthermore, Jatropha curcas L. can be used to reclaim land, as a hedge, provide employment, improve the environment and enhance the quality of rural life (Openshaw, 2000). Under semi-arid conditions Jatropha curcas root system has a possibility for reclaiming marginal soils by recycling nutrients from deeper soil layers, providing shadow to the soil and thereby reducing risks of erosion and desertification (Jongschaap et al., 2007b). Despite all the possible potentialities of growing Jatropha as a biofuel plant for either home consumption or commercial purpose it has not been economically viable mainly due to low seed yield, high cost of production, delayed production and uncompetitive, feedstock prices (Kgathi et al., 2017).

The photosynthesis process is a significant target to increase crop biomass production (Evans, 2013) and yield potential (Qu et al., 2017). The process is sensitive to environmental stresses (Kuhlgert et al., 2016), mostly extreme temperatures and low water content that can be detrimental to the photosynthesis apparatus. It has been observed that studies regarding photosynthesis are mainly focused on factors like water stress 
(Moseki and Dintwe, 2011); drought, and flooding stress (Osei-Bonsu et al., 2016); atmospheric environment (Fukuzawa et al., 2012) rather than organic amendments as a source of available soil nutrients. However, understanding poultry litter's influence and its biochar as a soil amendment on plant physiological properties will provide insights into the functional mechanisms responsible for the reported agronomic benefits of soil organic amendments.

The main objective of this study was to evaluate the effect of incorporating organic amendments on photosynthetic-related parameters of Jatropha curcas L. plant under greenhouse. Even though there are limited findings on this topic of research, the study hypothesizes that poultry litter and its biochar will significantly improve Jatropha curcas L.'s photosynthesis-related parameters due to their beneficial properties that improve soil properties, as previously mentioned in the above paragraphs.

\section{Materials and Methods}

\section{Experimental design and treatments}

A greenhouse experiment was conducted at the Department of Biology, University of Botswana, Gaborone, Botswana. Jatropha (Jatropha curcas L.) seeds were soaked in tap water for 2 hours to break dormancy before sowing them in moist growing media filled in seedling trays. After germination six weeks old seedlings were transplanted in pots. A randomised complete design was employed with three replication per treatment at different application rates of $0,0.5,1,2,3 \mathrm{gkg}^{-1}$. The experimental pots were previously filled with $6 \mathrm{~kg}$ of a homogenous mix of soil with three different organic soil amendments: (i) poultry litter (PL), (ii) poultry litter biochar pyrolyzed at temperatures of $350^{\circ} \mathrm{C}(\mathrm{BC} 350)$ and (iii) poultry litter biochar $750{ }^{\circ} \mathrm{C}$ (BC750). Henceforth, poultry litter, biochar pyrolyzed at $350^{\circ} \mathrm{C}$, and $750{ }^{\circ} \mathrm{C}$ are referred to as $\mathrm{PL}, \mathrm{BC} 350$, and $\mathrm{BC} 750$, respectively, in this study. The environmental conditions recorded were an average ambient temperature of $33.1{ }^{\circ} \mathrm{C}, 25 \%$ humidity, and plants were watered with $600 \mathrm{ml}$ water on alternate days. The analytical results for soil properties classified the soil as sandy by using a Multisizer analyzer, a soil $\mathrm{pH}_{\mathrm{H} 2 \mathrm{O}}$ value of 7.77, and electrical conductivity of $169.6 \mathrm{dS} / \mathrm{m}$ were recorded from a soil solution (Ibitoye, 2006). The moisture content of $0.94 \%$ was recorded after oven-dry analysis, and organic matter content of $0.37 \%$ with an oxidized organic carbon of $0.22 \%$ (Walkley and Black, 1934) was observed.

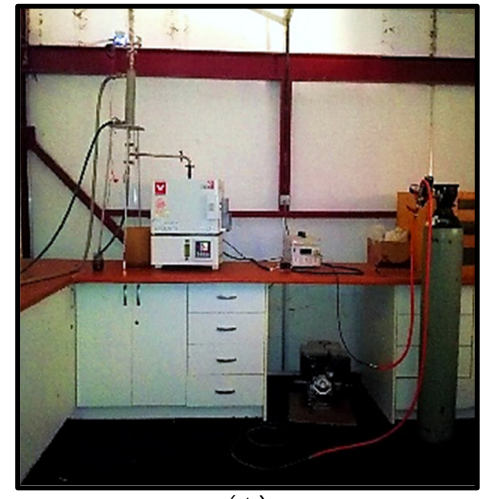

(A)

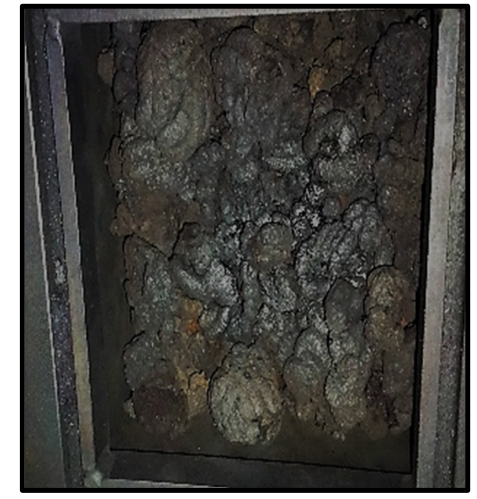

(B)

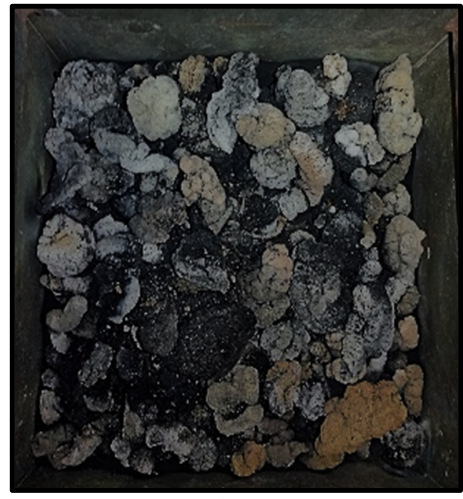

(C)

Figure 1. Biochar production equipment set-p (A), Poultry litter biochar produced at pyrolysis temperature of $350^{\circ} \mathrm{C}(\mathrm{B})$ and Poultry litter biochar produced at $750^{\circ} \mathrm{C}(\mathrm{C})$ pyrolysis temperature 


\section{Assessment of physiological parameters}

Vegetative traits: Leaf surface area $\left(\mathrm{m}^{2}\right)$

At physiological maturity, leaf area $\left(\mathrm{m}^{2}\right)$ was estimated based on a non-destructive method using leaf length and width dimensions (Montero et al., 2000) measured with a simple ruler and recorded to the nearest $0.1 \mathrm{~cm}$. Three leaves of each plant were selected and the length and width (widest part) were measured (length $\mathrm{X}$ width) and their average were multiplied with the total number of leaves of each plant as an estimated leaf surface area.

Chlorophyll fluorescence: Light-adapted Fv'/Fm' ratio, Quantum yield of PSII electron transport (ФPSII) and maximum photochemical efficiency of PSII (Estimated from dark-adapted Fv/Fm ratio)

For chlorophyll fluorescence properties a Fluorometer Monitoring System (FMS) (Hansatech Instruments Ltd. Narborough Road, Pentney, King's Lynn, Norfolk, PE32 1JL, England) for measurements at physiological maturity. The PAR / Temperature Leaf-Clip was used for light saturation measurements under ambient light conditions, whereas, for dark adaptation, adaptation leaf clips were put in the middle part of the adaxial leaf blade of each Jatropha plant simultaneously for about 15-20 minutes before taking measurements.

Physiological properties: Carbon dioxide uptake $\left(\mu \mathrm{molm}^{-2} \mathrm{~s}^{-1}\right)$, transpiration rate $\left(\mathrm{mmolm}^{-2} \mathrm{~s}^{-1}\right)$, and water use efficiency $\left(\mu \mathrm{mol}\left(\mathrm{CO}_{2}\right) \mathrm{mol}^{-1}\left(\mathrm{H}_{2} \mathrm{O}\right)\right)$ were determined.

Infrared gas analyser (LCi Photosynthetic System; ADC BioScientific Ltd) was used. An 'Open System' configuration in which fresh gas (air) passes through the PLC (Plant Leaf Chamber) continuously took measurements. The obtained results for Carbon dioxide uptake and transpiration rate were used to express water use efficiency on a leaf basis, as follows:

Leaf water use efficiency $\left(\mu \mathrm{mol}\left(\mathrm{CO}_{2}\right) \mathrm{mol}^{-1}\left(\mathrm{H}_{2} \mathrm{O}\right)=\right.$ photosynthesis rate $\left(\mu \mathrm{mol}^{-2} \mathrm{~s}^{-1}\right) /$ transpiration rate $\left(\mathrm{mmolm}^{-2} \mathrm{~s}^{-1}\right)$

\section{Statistical analysis}

A completely randomized design was used with three replicates for each treatment. The reported data of photosynthetic parameters represent the mean $+/-$ standard error. Mean variations were compared at $\mathrm{P}=$ $5 \%$, with ANOVA test followed using the Tukey HSD test $(\mathrm{p}<0.05)$ to test the significance of the difference between the treatments. IBM SPSS Statistic 22 software (IBM Corporation, Armonk, NY, USA) was used for performing the statistical analysis of the data.

\section{Results}

\section{Leaf surface area}

The response of leaf surface area $\left(\mathrm{m}^{2}\right)$ of Jatropha curcas $\mathrm{L}$. to different application rates of poultry litter and biochar is shown in Figure 2. Generally, a significant increase of leaf surface area with application rates in response to organic amendments has been observed (Figure 2). The amendment of PL had a greater effect on leaf surface growth $\left(1807 \mathrm{~m}^{2}\right)$ in comparison to BC350 $\left(1099 \mathrm{~m}^{2}\right)$; however, BC750 $\left(262 \mathrm{~m}^{2}\right)$ has shown less effect on leaf surface area. Furthermore, the application rate of $3 \mathrm{gkg}^{-1}(\mathrm{PL})$ exhibited an increase in leaf surface area. A statistically significant difference was observed among PL $(\mathrm{F}(4,10)=13.60, \mathrm{p}<0.001)$ and $\mathrm{BC} 350 \mathrm{~F}$ $(4,10)=34.66, \mathrm{p}<0.001)$ whereas BC750 treated plants exhibit no statistical means difference $(\mathrm{p}>0.05)$.

\section{Chlorophyll fluorescence}

Light-adapted $\mathrm{Fv}^{\prime} / \mathrm{Fm}^{\prime}$ ratio:

The efficiency of excitation energy transfer to open PSII centers was estimated (Moseki and Dintwe, 2011). Table 1 generally indicates the highest light-adapted $\mathrm{Fv}^{\prime} / \mathrm{Fm}^{\prime}$ ratio $(0.79 \pm 0.01)$ among the $\mathrm{BC} 350$ treated plants, significantly impacting BC750 treated plants contributing to the lowest ratio $(0.65 \pm 0.05)$. Among the organic amendments, only PL treated plants have a statistically significant difference $(\mathrm{F}(4,10)=$ 
4.43, $\mathrm{p}<0.05)$. Based on the application rate, control plants recorded the lowest light-adapted $\mathrm{Fv}^{\prime} / \mathrm{Fm}^{\prime}$ ratio than the treated plants. However, there was a slight decrease in the ratio for $\mathrm{BC} 350$ and $\mathrm{BC} 750$ treated plants at an application rate of $3 \mathrm{gkg}^{-1}$.

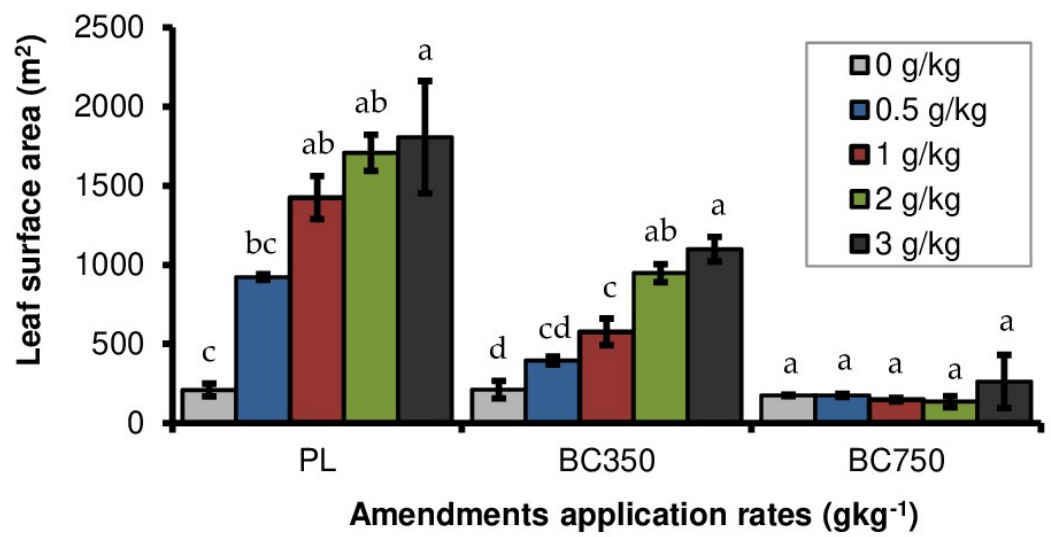

Figure 2. Leaf surface area $(\mathrm{M} \pm \mathrm{SE})$ of genus Jatropha plants in soils treated with different organic amendments (PL, BC350 \& BC750)

The trends reflect the variations in leaf surface area of Jatropha plants exposed to five different application rates $(0,0.5$, 1,2 , and $3 \mathrm{gkg}^{-1}$ ). Means with the same letter are not significantly different (Tukey HSD test, $\mathrm{p}<0.05$ ).

\section{Quantum yield of PSII electron transport (DPSII)}

ФPSII represents electron flow beyond PSII (Moseki and Dintwe, 2011), and it contains valuable information on the status of the photosynthetic apparatus. The findings of ФPSII (Table 1) were generally lower for $\mathrm{BC} 750$ ranging from $0.58 \pm 0.02$ to $0.68 \pm 0.01$ compared to BC350 and PL treated plants. However, PL significantly shows the highest $(0.75 \pm 0.01)$ ФPSII at an application rate of $3 \mathrm{gkg}^{-1}$. Moreover, the ФPSII for BC750 at different application rates were statistically insignificant $(\mathrm{p}>0.05)$.

\section{Maximum photochemical efficiency of PSII}

Estimates the efficiency of excitation energy capture by open PSII reaction centers and provides a rapid method for determining changes in the maximum quantum efficiency of PSII photochemistry (Moseki and Dintwe, 2011). As observed in the study results (Table 1), dark-adapted Fv/Fm ration for BC350 was higher $(0.78 \pm 0.01)$, with BC750 showing a lower ratio $(0.62 \pm 0.01)$ for treated plants. Although other treated plants recorded the lowest dark adaptation $\mathrm{Fv} / \mathrm{Fm}$ ratio, increasing the application rate of organic amendments increased the dark adaptation $\mathrm{Fv} / \mathrm{Fm}$ ratio in Jatropha plants.

\section{Carbon dioxide uptake, transpiration rate, and water use efficiency}

Generally, the carbon dioxide uptake (Table 2) increased with increased application rates, and increased plant nutrient levels may have contributed to that. A significant decrease in carbon dioxide $\left(\mathrm{CO}_{2}\right)$ uptake of BC750 compared to PL and BC350 treated plants was observed in Table 2. Moreover, there was a slight decrease of $\mathrm{CO}_{2}$ uptake with increasing application rate exhibited by $\mathrm{PL}\left(1 \mathrm{gkg}^{-1}\right)$ and $\mathrm{BC} 350\left(3 \mathrm{gkg}^{-1}\right)$. As for BC750 treated plants, $\mathrm{CO}_{2}$ uptake significantly decreased with increasing application rates compared to the control. There was no statistical difference $(\mathrm{P}>0.05)$ observed in plants grown in PL and BC750 treated soils.

The study results on transpiration rate displayed a significantly lower transpiration rate of BC750 treated plants with an increased application rate (Table 2). However, control plants have shown a higher transpiration rate than treated plants. The transpiration rate ranged from $0.44 \pm 0.08$ (No organic amendment) to $2.20 \pm 0.13$ (BC350 treated soils). 
Table 1. Effect of poultry derived biochar on chlorophyll fluorescence parameters of Jatropha plant at different application rates

\begin{tabular}{|c|c|c|c|}
\hline Application rate $\left(\mathrm{gkg}^{-1}\right)$ & PL & BC350 & BC750 \\
\hline \multicolumn{4}{|c|}{ Light-adapted Fv'/Fm' ratio } \\
\hline 0 & $0.66 \pm 0.02^{b}$ & $0.66 \pm 0.06^{\mathrm{a}}$ & $0.56 \pm 0.03^{\mathrm{a}}$ \\
\hline 0.5 & $0.77 \pm 0.01^{a}$ & $0.79 \pm 0.01^{\mathrm{a}}$ & $0.66 \pm 0.04^{a}$ \\
\hline 1 & $0.72 \pm 0.03^{\mathrm{ab}}$ & $0.76 \pm 0.03^{\mathrm{a}}$ & $0.69 \pm 0.01^{a}$ \\
\hline 2 & $0.72 \pm 0.01^{\mathrm{ab}}$ & $0.79 \pm 0.01^{\mathrm{a}}$ & $0.65 \pm 0.05^{\mathrm{a}}$ \\
\hline 3 & $0.74 \pm 0.02^{\mathrm{ab}}$ & $0.73 \pm 0.04^{a}$ & $0.72 \pm 0.03^{a}$ \\
\hline p-value & 0.03 & 0.10 & 0.07 \\
\hline \multicolumn{4}{|c|}{ Quantum yield of PSII electron transport ( } \\
\hline 0 & $0.62 \pm 0.02^{b}$ & $0.67 \pm 0.03^{\mathrm{a}}$ & $0.58 \pm 0.02^{\mathrm{a}}$ \\
\hline 0.5 & $0.71 \pm 0.01^{\mathrm{a}}$ & $0.70 \pm 0.03^{\mathrm{a}}$ & $0.57 \pm 0.06^{a}$ \\
\hline 1 & $0.72 \pm 0.00^{\mathrm{a}}$ & $0.74 \pm 0.02^{\mathrm{a}}$ & $0.56 \pm 0.03^{a}$ \\
\hline 2 & $0.75 \pm 0.02^{\mathrm{a}}$ & $0.74 \pm 0.01^{\mathrm{a}}$ & $0.59 \pm 0.03^{a}$ \\
\hline 3 & $0.75 \pm 0.01^{\mathrm{a}}$ & $0.71 \pm 0.04^{\mathrm{a}}$ & $0.68 \pm 0.01^{a}$ \\
\hline p-value & 0.001 & 0.45 & 0.23 \\
\hline \multicolumn{4}{|c|}{ Maximum photochemical efficiency of PSII (Estimated-dark adapted ratio) } \\
\hline 0 & $0.69 \pm 0.03^{\mathrm{a}}$ & $0.69 \pm 0.01^{\mathrm{d}}$ & $0.61 \pm 0.01^{\mathrm{b}}$ \\
\hline 0.5 & $0.74 \pm 0.01^{\mathrm{a}}$ & $0.75 \pm 0.01^{\mathrm{c}}$ & $0.62 \pm 0.01^{\mathrm{ab}}$ \\
\hline 1 & $0.74 \pm 0.01^{\mathrm{a}}$ & $0.73 \pm 0.01^{\mathrm{bcd}}$ & $0.65 \pm 0.02^{\mathrm{ab}}$ \\
\hline 2 & $0.75 \pm 0.02^{\mathrm{a}}$ & $0.78 \pm 0.01^{\mathrm{ac}}$ & $0.67 \pm 0.01^{\mathrm{a}}$ \\
\hline 3 & $0.75 \pm 0.01^{\mathrm{a}}$ & $0.76 \pm 0.01^{\mathrm{abc}}$ & $0.68 \pm 0.01^{a}$ \\
\hline p-value & 0.14 & 0.001 & 0.02 \\
\hline
\end{tabular}

Table 2. The effect of poultry derived biochar on carbon dioxide uptake $\left(\mu \mathrm{mol} \mathrm{m} \mathrm{m}^{-2}\right)$ and transpiration rate $\left(\mathrm{mol} \mathrm{m}^{-2} \mathrm{~s}^{-1}\right)$ at different application rates of Jatropha curcas $\mathrm{L}$.

\begin{tabular}{|c|c|c|c|}
\hline Application rate $\left(\mathrm{gkg}^{-1}\right)$ & PL & BC350 & BC750 \\
\hline \multicolumn{4}{|c|}{ Carbon dioxide uptake $\left(\mu \mathrm{mol} \mathrm{m} \mathrm{m}^{-2} \mathrm{~s}^{-1}\right)$} \\
\hline $\mathbf{0}$ & $1.66 \pm 0.44^{\mathrm{a}}$ & $1.62 \pm 0.14^{\mathrm{b}}$ & $1.84 \pm 0.73^{\mathrm{a}}$ \\
\hline 0.5 & $2.18 \pm 0.50^{\mathrm{a}}$ & $2.17 \pm 0.25^{\mathrm{ab}}$ & $1.62 \pm 0.37^{\mathrm{a}}$ \\
\hline 1 & $2.10 \pm 0.27^{\mathrm{a}}$ & $2.56 \pm 0.27^{\mathrm{ab}}$ & $1.83 \pm 0.26^{\mathrm{a}}$ \\
\hline 2 & $2.48 \pm 0.15^{\mathrm{a}}$ & $2.51 \pm 0.25^{\mathrm{ab}}$ & $1.28 \pm 0.03^{\mathrm{a}}$ \\
\hline 3 & $2.52 \pm 0.16^{\mathrm{a}}$ & $2.67 \pm 0.04^{\mathrm{a}}$ & $1.40 \pm 0.37^{\mathrm{a}}$ \\
\hline p-value & 0.42 & $\mathbf{0 . 0 3}$ & 0.83 \\
\hline \multicolumn{4}{|c|}{ Transpiration rate $\left(\mathrm{mmol} \mathrm{m}^{-2} \mathrm{~s}^{-1}\right)$} \\
\hline $\mathbf{0}$ & $0.44 \pm 0.08^{\mathrm{b}}$ & $0.88 \pm 0.21^{\mathrm{b}}$ & $0.66 \pm 0.23^{\mathrm{a}}$ \\
\hline 0.5 & $1.02 \pm 0.10^{\mathrm{ab}}$ & $1.41 \pm 0.16^{\mathrm{b}}$ & $0.98 \pm 0.02^{\mathrm{a}}$ \\
\hline 1 & $1.30 \pm 0.14^{\mathrm{ab}}$ & $1.48 \pm 0.11^{\mathrm{b}}$ & $1.31 \pm 0.18^{\mathrm{a}}$ \\
\hline 2 & $1.35 \pm 0.31^{\mathrm{ab}}$ & $1.31 \pm 0.08^{\mathrm{b}}$ & $0.84 \pm 0.14^{\mathrm{a}}$ \\
\hline 3 & $2.06 \pm 0.40^{\mathrm{a}}$ & $2.20 \pm 0.13^{\mathrm{a}}$ & $0.64 \pm 0.11^{\mathrm{a}}$ \\
\hline p-value & 0.01 & 0.001 & 0.62 \\
\hline
\end{tabular}

Carbon dioxide uptake means photosynthetic rate. Means denoted by a different letter indicate statistical differences between treatments (Tukey HSD, $\mathrm{p}<0.05$ test). 


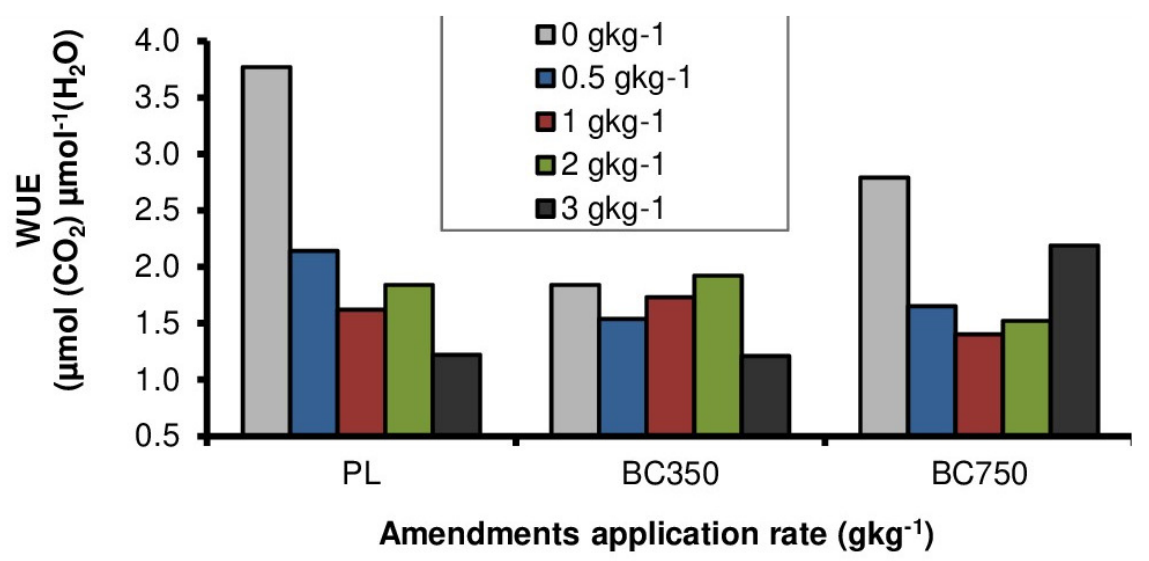

Figure 3. Water use efficiency (WUE) in $\mu \mathrm{mol}\left(\mathrm{CO}_{2}\right) \mathrm{mol}^{-1}\left(\mathrm{H}_{2} \mathrm{O}\right)$ of Jatropha plants treated with different soil organic amendment (PL, BC350, and BC750) considering three replications at five different application rates $\left(0,0.5,1,2\right.$, and $\left.3 \mathrm{gkg}^{-1}\right)$

Moreover, Figure 3 indicates high water use efficiency (WUE) for the control plants with a slight decrease in the application rate of organic amendments except for BC750 at an application rate of $3 \mathrm{gkg}^{-1}$. WUE decreased with the application rate for PL treated plants and for BC350 treated plants; however, there was a slight increase at an application rate of 1 to $2 \mathrm{gkg}^{-1}$. Further, plants grown in BC750 treated soil have higher water use efficiency values $2.2 \mu \mathrm{mol}\left(\mathrm{CO}_{2}\right) \mu \mathrm{mol}^{-1}\left(\mathrm{H}_{2} \mathrm{O}\right)$ compared to $\mathrm{PL}$ and $\mathrm{BC} 350$ treatments and BC750 treated plants WUE ranges from 1.7 to $2.2 \mu \mathrm{mol}\left(\mathrm{CO}_{2}\right) \mu \mathrm{mol}^{-1}\left(\mathrm{H}_{2} \mathrm{O}\right)$.

\section{Discussion}

Plant stress, either biotic or abiotic, is one of the main factors that may effectively trigger physiological disturbances in plants (Aucique-Perez et al., 2020) due to its effect on chlorophyll parameters. For instance, the greater the plant stress, the fewer the open reaction centers available and the lower $\mathrm{Fv} / \mathrm{Fm}$ (Murchie and Lawson, 2013) due to photoinhibition, which is brought about by a drop in maximum light absorption efficiency. Furthermore, deficiency of plant-available nutrients like manganese $(\mathrm{Mn})$, potassium $(\mathrm{K})$, molybdenum $(\mathrm{Mo})$, nitrogen $(\mathrm{N})$, magnesium $(\mathrm{Mg})$, and calcium $(\mathrm{Ca})$ are amongst the factors that influence the production of chlorophyll (Morgan and Connolly, 2013). Moreover, the lower plant available nutrients below the optimum requirement may cause stunted growth, death of plant tissues, and yellowing of plant leaves (Bottrill et al., 1970) that will eventually depress the photosynthesis rate. For instance, leaf senescence is also influenced by $\mathrm{N}$ and is related to a decline in photosynthetic capacity. According to (Bottrill et al., 1970), the resupply of nutrients in algae may result in the rapid recovery of photosynthesis, resulting from new chlorophyll. Hence available plant nutrients are required for increased plant productivity by improving the photosynthesis process that produces food (glucose) for the plants.

\section{Leaf surface area}

It is evident from the results of this study that organic amendments improved the leaf surface area of plants grown in treated soil compared to control plants (Figure 2). High nutrient content in PL (Bolan et al., 2010) may have increased plant-available nutrients in the soil, thus improving soil fertility and promoting plant growth (Yu et al., 2018). For instance, nitrogen strongly influences photosynthesis performance and biomass production (Zivcak et al., 2014), the larger the leaf surface area absorbs maximal light (Moseki and Dintwe, 2011) that may contribute to a higher photosynthetic rate, ultimately improving plant growth. Additionally, 
other parameters that may be enhanced by the increase of poultry litter application rate are total chlorophyll content, carbon content, water holding capacity, and decreased bulk density of soil, all of which interplay to increase leaf area and total chlorophyll content of the plant (Enujeke, 2013). This is consistent with the findings of (Onwu et al., 2018), who reported that increased poultry manure application significantly increases leaf area of physic nut because of sufficient nitrogen availability, which improves the vegetative growth of the crop.

\section{Chlorophyll fluorescence}

Plant stress because of limited available plant nutrients may have affected photosynthetic apparatus; hence lower light-adapted Fv'/Fm' ratio, ФPSII levels, and dark adaptation Fv/Fm ration (Table 1) were observed on plants in soils treated with an organic amendment that has lower nutrient content (BC750). The Quantum yield of PSII represents electron flow beyond PSII (Dintwe and Moseki, 2011). In corroboration (Zivcak et al., 2014), organic amendments contributed to the lower quantum yield of PSII ( $\Phi P S I I<0.8$ ) value, and the decrease of ФPSII may show that the proportion of energy harnessed by chlorophyll to stimulate the photochemical process is not efficiently used (Aucique-Perez et al., 2020). Photosynthesis increases linearly with the increase in leaf $\mathrm{N}$ content (Bassi et al., 2018). The lower the nitrogen content contributes to the lower the pigment-protein complexes in PSII, PSI, and light-harvesting complexes (Murchie and Lawson, 2013), later on, values may have contributed to the decreased DPSII levels in BC750 treated plants because of failure to transfer required excitation energy to PSII centers.

Furthermore, Table 1 displays the trend for light adaptation Fv'/Fm' ratio correlates with DPSII; explaining that the lower the light-adapted $\mathrm{Fv}^{\prime} / \mathrm{Fm}^{\prime}$ ratio, the lesser the $\Phi$ PSII expected or vice versa. As for dark-adapted Fv/Fm ratio, lower values are linked with the results of light-adapted Fv'/Fm' and DPSII, including leaf nitrogen content. Based on Table 1, the lower dark-adapted Fv'/Fm' in plants treated with BC750 compared to BC350 and PL may be due to the effects of changing ФPSII levels as they significantly affect dark-adapted Fv'/Fm'. The lower the ФPSII levels, the lower the levels of dark-adapted Fv/Fm ratio, as the energy captured efficiency depends on the electron flow beyond PSII reaction centers. Lower chlorophyll molecules may have resulted in lowering energy molecules (ATP and NADPH), necessary for the dark reaction process.

\section{Carbon dioxide uptake, transpiration rate, and water use efficiency (WUE)}

As observed in Table 2 a lower carbon dioxide $\left(\mathrm{CO}_{2}\right)$ uptake rate in $\mathrm{BC} 750$ compared to $\mathrm{BC} 350$ and PL may be due to the inadequate energy absorbed by the chlorophyll molecules for photochemistry. Additionally, a decrease in the $\mathrm{CO}_{2}$ conductance (Longstreth and Nobel, 1980) may have reduced the $\mathrm{CO}_{2}$ uptake rate at low nutrient levels. Increased photosynthesis rate may have been significant due to the increased leaf surface area at the highest application rate for plants grown in soils treated with organic amendments (PL) with the highest nutrient content (Bolan et al., 2010) necessary for biomass growth (Longstreth and Nobel, 1980).

Furthermore, increasing pyrolysis temperatures (Gai et al., 2014) during biochar production from manure and biosolids results in biochars with decreasing hydrolysable organic $\mathrm{N}$ because aromatic and heterocyclic structures increase (Clough et al., 2013; Sun et al., 2016) and nutrients susceptible to volatilization, violate after pyrolysis (Gaskin et al., 2008). The deficiency of nitrogen strongly influences crop photosynthetic performance and biomass production (Zivcak et al., 2014) as it is a significant component of photosynthetic apparatus (Bassi et al., 2018). Therefore, limited soil and leaf nitrogen composition (Alvino and Sorrentino, 1996) may lower photosynthesis rate due to lower chlorophyll parameters as shown by plants grown in BC750 treated soils (Table 2). For this reason, the photosynthesis rate significantly increased in plants grown in PL and BC350 treated soils (Table 2), probably due to high nitrogen content (Bolan et al., 2010). Besides nitrogen, potassium $(\mathrm{K})$ content may have influenced $\mathrm{CO}_{2}$ uptake because it is necessary for stomatal opening or closing and cellular growth, and its deficiency leads to chlorosis (Morgan and Connolly, 2013). The 
lower $\mathrm{K}$ concentrations lead to the lesser stomatal opening that results in lesser $\mathrm{CO}_{2}$ concentration, consequently lowering the carbon rate incorporated into carbohydrates.

Moreover, the higher photosynthetic rate in PL and BC350 (Table 2) may be due to the increased number of leaves (Figure 2Error! Reference source not found.) that may as well have increased the capacity chlorophyll content (Halim et al., 2018) required for the process of photosynthesis. Also, the study results of photosynthesis rate were lower than the recommended range of $10-25 \mu \mathrm{molm}^{-2} \mathrm{~s}^{-1}$ (Fukuzawa et al., 2012) or 9$18 \mu \mathrm{mol}\left(\mathrm{CO}_{2}\right) \mathrm{m}^{-2} \mathrm{~s}^{-1}$ (Yong et al., 2010) despite the increase of organic amendments application rate; therefore higher application rate than $3 \mathrm{gkg}^{-1}$ may increase photosynthesis rate to the optimum level. Furthermore, Murchie and Lawson (2013) and Zivcak et al. (2014), stated that the more profound photosynthesis rate increase below 0.80-0.83 indicates the organic amendment's negative influence on photosynthetic apparatus. However, $\mathrm{BC} 350$ has a slightly lower $\mathrm{CO}_{2}$ uptake compared to recommended maximum photosynthetic rate (Murchie and Lawson, 2013; Zivcak et al., 2014), indicating that a slight increase of nitrogen content may increase the photosynthesis rate to its optimum level. According to Zoghi et al. (2019), the increase of biochar application rates results in higher photosynthesis rates, which agrees with the study results as shown in Table 2. Additionally, WUE (Figure 3) may have a significant contribution to the lower photosynthetic rate output (Table 2) as WUE lowers the stomatal conductance (Zoghi et al., 2019), eventually reducing plant growth (Ruggiero et al., 2017) as observed in this study.

As for transpiration rate, the increased leaf surface area (Figure 2) may have affected the transpiration rate effectively as reflected in Table 2 . The plants that have shown larger leaf surface area (Figure 2) exhibit an increased transpiration rate (Table 2 ) and vice versa. Nonetheless, the highest transpiration rate recorded was within the maximum range of $2-6 \mathrm{mmolm}^{-2} \mathrm{~s}^{-1}$ (Fukuzawa et al., 2012). Also, there was a slight variation of transpiration rate; this may be due to the dropping of leaves by Jatropha plants as a water conservation management technique. For WUE, it is the ratio of water used by the plant metabolism to water lost by the plant through transpiration (Ruggiero et al., 2017). The study results show that WUE increased in BC750 treated plants compared to PL and BC350 (Figure 3). Moreover, the PL and BC350 WUE generally decreased with the increase of application rate compared to the control. The increase of WUE in BC750 and control may be due to the smaller leaf surface area (Figure 2), thus less transpiration rate (Table 2); hence more water use efficiency. As for BC750 treated plants, the larger surface area of biochar (BC750) can increase soil water holding capacity (Hui et al., 2018); therefore, the small pores of biochar (Revell, 2011) and high porosity with a larger surface area (Brantley et al., 2015) help with the water holding capacity of sandy soils, eventually improving water use efficiency (Basso and Ritchie, 2012). The leaf surface area also affects the transpiration rate and water use efficiency as these physiological processes occur in the leaves (Nakanwagi et al., 2018). For instance, the larger leaf surface area for BC350 was linked with a higher transpiration rate and reduced WUE as the application rate increased; however, the opposite occurred in BC750 treated plants.

Furthermore, underwater deficit biochar significantly $(\mathrm{P}<0.01)$ improves photosynthesis, stomatal conductance, transpiration, and xylem water potential (Zoghi et al., 2019), and that was not the case in this study. According to Halim et al. (2018) study, photosynthesis rate increased under conditions of lower transpiration rate and high WUE when plants treated with compost that is not the case in this study, probably due to the organic amendment used that has a lower content of nitrogen, which is essential for the process of photosynthesis.

\section{Conclusions}

The incorporation of organic amendments in soil has significantly influenced Jatropha photosynthesisrelated parameters. Among the organic amendments used, biochar pyrolyzed at $350^{\circ} \mathrm{C}$ improved Jatropha photosynthetic-related parameters. Therefore, the study considers BC350 suitable for Jatropha growth as it has the potential to improve Jatropha photosynthesis-related parameters that will eventually enhance plant growth. 


\section{Authors' Contributions}

Conceptualization: BLM and OD; Methodology: BLM and OD; Formal analysis: BLM; Investigation: BLM; Resources: BM; Writing-original draft preparation: BLM; Writing-review and editing: BLM and BM; Supervision: OD and BM; Funding acquisition: BM.

All authors read and approved the final manuscript.

\section{Acknowledgements}

This work was supported by the Botswana Japan Jatropha research project financially and the University of Botswana (Department of Biological Sciences) to allocate the experimental site (Greenhouse) and their assistance with measuring devices.

\section{Conflict of Interests}

The authors declare that there are no conflicts of interest related to this article.

\section{References}

Agbogidi OM, Akparobi SO, Eruotor PG (2013). Health and environmental benefits of Jatropha curcas Linn. Applied Science Reports 1(2):36-39.

Alvino A, Sorrentino G (1996). Highlight effects on chlorophyll fluorescence and light interception in Lilium. Advances in Horticultural Science 10(2):70-78. https://www.jstor.org/stable/42881399

Aucique-Perez CE, Daza ES, Ávila-Diazgranados RA, Omero HM (2020). Chlorophyll a fluorescence and leaf temperature are early indicators of oil palm diseases. Scientia Agricola 77(2):e20180106. https://doi.org/10.1590/1678-992x-2018-0106

Bassi D, Menossi M, Mattiello L (2018). Nitrogen supply influences photosynthesis establishment along the sugarcane leaf. Scientific Reports 8(1):1-13. https://doi.org/10.1038/s41598-018-20653-1

Basso B, Ritchie JT (2012). Assessing the impact of management strategies on water use efficiency using soil-plantatmosphere models. Vadose Zone Journal 11(3):vzj2011.0173. https://doi.org/10.2136/vzj2011.0173

Biederman LA, Harpole WS (2013). Biochar and its effects on plant productivity and nutrient cycling: A meta-analysis. GCB Bioenergy 5(2):202-214. https://doi.org/10.1111/gcbb.12037

Blesgraaf RAR (2009). Water use of Jatropha hydrological impacts of Jatropha curcas L. Delft University of Technology, South Africa.

Bohara H, Dodla S, Wang JJ, Darapuneni M, Acharya BS, Magdi S, Pavuluri K (2019). Influence of poultry litter and biochar on soil water dynamics and nutrient leaching from a very fine sandy loam soil. Soil and Tillage Research 189:44-51.

Bolan NS, Szogi AA, Chuasavathi T, Seshadri B, Rothrock JrMJ, Panneerselvam P (2010). Uses and management of poultry litter. World's Poultry Science Journal 66:673-698. https://doi.org/10.1017/S0043933910000656

Bolan N, Szogi A, Seshadri B, Chuasavathi T (2010). The management of phosphorus in poultry litter. 19th World Congress of Soil Science, Soil Solutions for a Changing World, 1-6 August 2010, Brisbane, Australia, 317-320.

Bottrill DE, Possingham JV, Kriedemann PE (1970). The effect of nutrient deficiencies on phosynthesis and respiration in spinach. Plant and Soil 32(1-3):424-438. https://doiorg/10.1007/BF01372881

Brantley KE, Brye KR, Savin MC, Longer DE (2015). Biochar source and application rate effects on soil water retention determined using wetting curves. Open Journal of Soil Science 5(01):1. https://soi.org/10.4236/ojss.2015.51001

Chan KY, Van Zwieten L, Meszaros I, Downie A, Joseph S (2008). Agronomic values of green waste biochar as a soil amendment. Soil Research 45(8):629-634. https://doi.org/10.1071/SR07109 
Chapin III FS (1980). The mineral nutrition of wild plants. Annual Review of Ecology and Systematics 11(1):233-260. https://doi.org/10.1146/annurev.es.11.110180.001313

Clough TJ, Condron LM (2010). Biochar and the nitrogen cycle: Introduction. Journal of Environmental Quality 39(4):1218-1223. https://doi.org/10.2134/jeq2010.0204

Clough TJ, Condron LM, Kammann C, Müller C (2013). A review of biochar and soil nitrogen dynamics. Agronomy 3(2):275-293. https://doi.org/10.3390/agronomy3020275

Dias LAS, Missio RF, Dias DCFS (2012). Review Antiquity, botany, origin and domestication of Jatropha curcas (Euphorbiaceae), a plant species with potential for biodiesel production. Genetics and Molecular Research 11(3):2719-2728. https://doi.org/10.4238/2012.June.25.6

Dintwe K, Moseki B (2011). Effect of water stress on photosynthetic characteristics of two sorghum cultivars. University of Botswana. http://hdl.handle.net/10311/962

Enujeke EC (2013). Effects of poultry manure on growth and yield of improved maize in Asaba area of delta state, Nigeria. IOSR Journal of Agriculture and Veterinary Science 4(5):24-30.

Evans JR (2013). Improving photosynthesis. Plant Physiology 162(4):1780-1793. https://doi.org/10.1104/pp.113.219006

Fukuzawa Y, Tominaga J, Akashi K, Yabuta S, Ueno M, Kawamitsu Y (2012). Photosynthetic gas exchange characteristics in Jatropha curcas L. Plant Biotechnology 12-0406.

Gai X, Wang H, Liu J, Zhai L, Liu S, Ren T, Liu H (2014). Effects of feedstock and pyrolysis temperature on biochar adsorption of ammonium and nitrate. PloS One 9(12). https://doi.org/10.1371/journal.pone.0113888

Gaskin JW, Steiner C, Harris K, Das KC, Bibens B (2008). Effect of low-temperature pyrolysis conditions on biochar for agricultural use. Transactions of the ASABE 51(6):2061-2069. https://doi.org/10.13031/2013.25409

Geply OA, Baiyewu RA, Adegoke IA, Ayodele OO, Ademola IT (2011). Pakistan Journal of Nutrition 10(10):952-954.

Halim A, Sa'adah N, Abdullah R, Karsani SA, Osman N, Panhwar QA, Ishak CF (2018). Influence of soil amendments on the growth and yield of rice in acidic soil. Agronomy 8(9):165. https://doi.org/10.3390/agronomy8090165

Hui D, Yu C-L, Deng Q, Saini P, Collins K, Koff JD (2018). Weak effects of biochar and nitrogen fertilization on switchgrass photosynthesis, biomass, and soil respiration. Agriculture 8(9):143.

Ibitoye AA (2006). Laboratory manual on basic soil analysis. Foladave Nigeria Limited. Ibadan, pp 16-36.

Jongschaap REE, Corré WJ, Bindraban PS, Brandenburg WA (2007a). Claims and facts on Jatropha curcas L.: Global Jatropha curcas evaluation. Breeding and propagation programme. Plant Research International.

Jongschaap REE, Corré WJ, Bindraban PS, Brandenburg WA (2007b). Claims and facts on Jatropha curcas L.: Global Jatropha curcas evaluation. Breeding and propagation programme. Plant Research International.

Kalaji HM, Bąba W, Gediga K, Goltsev V, Samborska IA, Cetner MD ..., Karmowska K. (2018). Chlorophyll fluorescence as a tool for nutrient status identification in rapeseed plants. Photosynthesis Research 136(3):329-343. https://doi.org/10.1007/s11120-017-0467-7

Kalaji HM, Oukarroum A, Alexandrov V, Kouzmanova M, Brestic M, Zivcak M, ... Goltsev V (2014). Identification of nutrient deficiency in maize and tomato plants by in vivo chlorophyll a fluorescence measurement. Plant Physiology and Biochemistry 81:16-25. https://doi.org/10.1016/j.plaphy.2014.03.029

Kgathi DL, Mmopelwa G, Chanda R, Kashe K, Murray-Hudson M (2017). A review of the sustainability of Jatropha cultivation projects for biodiesel production in southern Africa: Implications for energy policy in Botswana. Agriculture, Ecosystems and Environment 246:314-324. https://doi.org/10.1016/j.agee.2017.06.014

Khan AUH, Iqbal M, Islam KR (2007). Dairy manure and tillage effects on soil fertility and corn yields. Bioresource Technology 98(10):1972-1979. https://doi.org/10.1016/j.biortech.2006.07.041

Kuhlgert S, Austic G, Zegarac R, Osei-Bonsu I, Hoh D, Chilvers MI, ... Weebadde P (2016). MultispeQ Beta: A tool for large-scale plant phenotyping connected to the open PhotosynQ network. Royal Society Open Science 3(10):160592. https://doi.org/10.1098/rsos.160592

Kumar A, Sharma S (2008). An evaluation of multipurpose oil seed crop for industrial uses (Jatropha curcas L.): A review. Industrial Crops and Products 28(1):1-10. https://doi.org/10.1016/j.indcrop.2008.01.001

Laghari M, Naidu R, Xiao B, Hu Z, Mirjat MS, Hu M, ... Fazal S (2016). Recent developments in biochar as an effective tool for agricultural soil management: A review. Journal of the Science of Food and Agriculture 96(15):4840-4849. https://doi.org/10.1002/jsfa.7753

Laird DA (2008). The charcoal vision: A win-win-win scenario for simultaneously producing bioenergy, permanently sequestering carbon, while improving soil and water quality. Agronomy Journal 100(1):178-181. https://doi.org/10.2134/agronj2007.0161 
Leela T, Naresh B, Reddy MS, Madhusudhan NC, Cherku, PD (2011). Morphological, physico-chemical and micropropagation studies in Jatropha curcas L. and RAPD analysis of the regenerants. Applied Energy 88(6):20712079. https://doi.org/10.1016/j.apenergy.2010.12.080

Li Z, Schneider RL, Morreale SJ, Xie Y, Li C, Li J (2018). Woody organic amendments for retaining soil water, improving soil properties and enhancing plant growth in desertified soils of Ningxia, China. Geoderma 310:143-152. https://doi.org/10.1016/j.geoderma.2017.09.009

Longstreth DJ, Nobel PS (1980). Nutrient influences on leaf photosynthesis. Plant Physiology 65(3):541-543. https://doi.org/10.1104/pp.65.3.541

Mahajan R, Pongen I, Dutt S, Chand R, Rana RC (2009). Oil content variation of purging nut (Jatropha curcas Linn.) seeds in Uttarakhand. Annals of Forestry 17(1):97-100.

Matsumoto H, Yeasmin R, Kalemelawa F, Aranami M, Inoue M, Nishihara E (2014). Effect of soil water environment and simulated savanna climate on growth and mineral nutrition in Jatropha curcas L. Agricultural Science 2(3):1322

Montero FJ, De Juan JA, Cuesta A, Brasa A (2000). Nondestructive methods to estimate leaf area in Vitis vinifera L. HortScience 35(4):696-698. https://doi.org/10.21273/HORTSCI.35.4.696

Morgan JB, Connolly EL (2013). Plant-soil interactions: Nutrient uptake. Nature Education Knowledge 4(8):2.

Moseki B, Dintwe K (2011). Effect of water stress on photosynthetic characteristics of two sorghum cultivars. The African Journal of Plant Science and Biotechnology 89-91.

Murchie EH, Lawson T (2013). Chlorophyll fluorescence analysis: A guide to good practice and understanding some new applications. Journal of Experimental Botany 64(13):3983-3998. https://doi.org/10.1093/jxb/ert208

Nakanwagi MJ, Sseremba G, Kabod NP, Masanza M, Kizito EB (2018). Accuracy of using leaf blade length and leaf blade width measurements to calculate the leaf area of Solanum aethiopicum Shum group. Heliyon 4(12):e01093. https://doi.org/10.1016/j.heliyon.2018.e01093

Onwu AC, Osujieke ND, Gani AT, Ali A (2018). Influence of organic fertilizer (Nomau ${ }^{\circ}$ ) on soil, leaf nutrient content, growth and yield of physic nut (Jatropha curcas) in Makurdi, North Central, Nigeria. Asian Journal of Soil Science and Plant Nutrition 1-11. https://doi.org/10.9734/AJSSPN/201

Openshaw K (2000). A review of Jatropha curcas: An oil plant of unfulfilled promise. Biomass and Bioenergy 19(1):1-15. https://doi.org/10.1016/S0961-9534(00)00019-2

Osei-Bonsu I, Hoh D, Cruz J, Savage L, Kuhlgert S, TerAvest D, ... Kramer D (2016). Variation in chlorophyll fluorescence-derived photosynthetic parameters and SPAD of cowpea genotypes subjected to drought and flooding stress at the pod filling stage. Pan-African Grain Legume and World Cowpea Conference.

Qu M, Zheng G, Hamdani S, Essemine J, Song Q, Wang H, ... Zhu XG (2017). Leaf photosynthetic parameters related to biomass accumulation in a global rice diversity survey. Plant Physiology 175(1):248-258. https://doi.org/10.1104/pp.17.00332

Rajaona AM, Sutterer N, Asch F (2012). Potential of waste water use for Jatropha cultivation in arid environments. Agriculture 2(4):376-392. https://doi.org/10.3390/agriculture2040376

Revell KT, Maguire RO, Agblevor FA (2012). Influence of poultry litter biochar on soil properties and plant growth. Soil Science 177(6):402-408. https://doi.org/10.1097/SS.0b013e3182564202

Revell KT (2011). The effect of fast pyrolysis biochar made from poultry litter on soil properties and plant growth $[\mathrm{PhD}$ Thesis]. Virginia Tech.

Roberts KG, Gloy BA, Joseph S, Scott NR, Lehmann J (2009). Life cycle assessment of biochar systems: Estimating the energetic, economic and climate change potential. Environmental Science and Technology 44(2):827-833. https://doi.org/10.1021/es902266r

Ruggiero A, Punzo P, Landi S, Costa A, Van Oosten MJ, Grillo S (2017). Improving plant water use efficiency through molecular genetics. Horticulturae 3(2):31. https://doi.org/10.3390/horticulturae3020031

Scotti R, Bonanomi G, Scelza R, Zoina A, Rao MA (2015). Organic amendments as sustainable tool to recovery fertility in intensive agricultural systems. Journal of Soil Science and Plant Nutrition 15(2):333-352. https://doi.org/10.4067/S0718-95162015005000031

Steiner C, Das KC, Melear N, Lakly D (2010). Reducing nitrogen loss during poultry litter composting using biochar. Journal of Environmental Quality 39(4):1236-1242. https://doi.org/10.2134/jeq2009.0337

Sun J, Ye M, Peng S, Li Y (2016). Nitrogen can improve the rapid response of photosynthesis to changing irradiance in rice (Oryza sativa L.) plants. Scientific Reports 6(1):1-10. https://doi.org/10.1038/srep31305 
Tatikonda L, Wani SP, Kannan S, Beerelli N, Sreedevi TK, Hoisington DA, ... Varshney RK (2009). AFLP-based molecular characterization of an elite germplasm collection of Jatropha curcas L., a biofuel plant. Plant Science 176(4):505-513. https://doi.org/10.1016/j.plantsci.2009.01.006

van Zwieten L (2018). The long-term role of organic amendments in addressing soil constraints to production. Nutrient Cycling in Agroecosystems 111(2):99-102. https://doi.org/10.1007/s10705-018-9934-6

Walkley A, Black IA (1934). An examination of the Degtjareff method for determining soil organic matter, and a proposed modification of the chromic acid titration method. Soil Science 37(1):29-38. https://doi.org/10.1097/00010694193401000-00003

Xu CY, Hosseini-Bai S, Hao Y, Rachaputi RC, Wang H, Xu Z, Wallace H (2015). Effect of biochar amendment on yield and photosynthesis of peanut on two types of soils. Environmental Science and Pollution Research 22(8):61126125. https://doi.org/10.1007/s11356-014-3820-9

Yong JWH, Ng YF, Tan SN, Chew AYL (2010). Effect of fertilizer application on photosynthesis and oil yield of Jatropha curcas L. Photosynthetica 48(2):208-218. https://doi.org/10.1007/s11099-010-0026-3

Yu CH, Wang SL, Tongsiri P, Cheng MP, Lai HY (2018). Effects of poultry-litter biochar on soil properties and growth of water spinach (Ipomoea aquatica Forsk.). Sustainability 10(7):2536. https://doi.org/10.3390/su10072536

Zivcak M, Olsaovska K, Slamka P, Galambosova J, Rataj V, Shao H-B, ... Brestic M (2014). Measurements of chlorophyll fluorescence in different leaf positions may detect nitrogen deficiency in wheat. Zemdirbyste-Agriculture 101(4):437-444. http://www.zemdirbyste-agriculture.It/1014_str56/

Zoghi Z, Hosseini SM, Kouchaksaraei MT, Kooch Y, Guidi L (2019). The effect of biochar amendment on the growth, morphology and physiology of Quercus castaneifolia seedlings under water-deficit stress. European Journal of Forest Research 138(6):967-979.
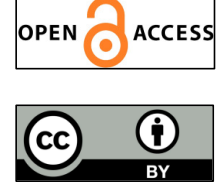

The journal offers free, immediate, and unrestricted access to peer-reviewed research and scholarly work. Users are allowed to read, download, copy, distribute, print, search, or link to the full texts of the articles, or use them for any other lawful purpose, without asking prior permission from the publisher or the author.

License - Articles published in Notulae Botanicae Horti Agrobotanici Cluj-Napoca are Open-Access, distributed under the terms and conditions of the Creative Commons Attribution (CC BY 4.0) License. (c) Articles by the authors; UASVM, Cluj-Napoca, Romania. The journal allows the author(s) to hold the copyright/to retain publishing rights without restriction. 